\title{
GRAFISMOS PUROS NOS SÍTIOS ARQUEOLÓGICOS DO PARQUE NACIONAL DO CATIMBAU-PE
}

Anderson Luiz Silva de Oliveira ${ }^{i}$

Daniela Cisneiros ${ }^{\mathrm{ii}}$

Marília Perazzo

Resumo: O Parque Nacional do Catimbau ocupa posição de destaque no cenário arqueológico do estado de Pernambuco, pois dispõe de um significativo e considerável acervo gráfico, com pinturas e gravuras rupestres de caráter reconhecível e não reconhecível. Os grafismos puros estão inseridos em um conjunto específico dentro do universo imagético dos grupos pré-históricos, cujo significado não nos é apresentado de forma imediata. Este trabalho procura identificar o perfil gráfico destas figuras, pontuando a diferenciação entre as similaridades e diferenças entre elas. Os procedimentos analítico para o desenvolvimento desta caracterização tem a intenção de discorrer sobre os aspectos técnicos e cenográficos desses grafismos através da eleição de variáveis que envolvem forma, cor, morfologias e técnicas de pintura. Palavras-chave: Registro Rupestre, Grafismos Puros, Parque Nacional do Catimbau.

Abstract: The Catimbau National Park occupies a prominent position in the archaeological scenery of the state of Pernambuco, as it has a significant and considerable graphic collection, with paintings and engravings of recognizable and unrecognizable character. Pure graphics are embedded in a specific set within the imaginary universe of prehistoric groups, the meaning of which is not immediately. This paper seeks to identify the graphic profile of these figures, punctuating the differentiation between similarities and differences between them. The analytical procedures for the

' Discente do Programa de Pósgraduação em Arqueologia da UFPE.

ii Docente do Departamento de Arqueologia da UFPE.

iii Universidade Estadual de São Paulo development of this characterization are intended to discuss the technical and scenographic aspects of these graphics through the choice of variables that involve their shape, color, morphologies and painting techniques.

Keywords: Rock Registry, Pure Graphism, Catimbau National Park. 


\title{
Introdução
}

O estudo dos registros rupestres dentro da Arqueologia reveste-se de uma complexidade ímpar. Essas manifestações desenvolvidas em períodos pré-históricos tem colocado um desafio preponderante, no tocante a sua origem, finalidade, sentidos e significados. Esse desafio aumenta, dada muitas vezes a impossibilidade de contextuar arqueológica e cronologicamente os grafismos, seja através de datações diretas ou através de demais vestígios materiais.

Dentro do campo da Arqueologia, os registros rupestres são compreendidos como os registros (gravuras e pinturas) realizados pelos grupos humanos e localizados em suportes rochosos, com diferentes morfologias. Existe ainda hoje um forte debate sobre as terminologias para designar esse tipo de vestígio. Entre essas terminologias pode-se destacar: arte rupestre, vestígio rupestre, registro rupestre e grafismo rupestres. A utilização do termo arte rupestre (Rock art), configura-se na terminologia dominante em artigos sobre o assunto. Apesar da popularidade do termo e de sua utilização convencional na arqueologia, esse termo termina por ser um pouco questionável quando sugere serem essas formas um tipo de arte para as populações pré-históricas (Comerlato, 2005).

No Brasil tem-se observado uma predileção para o não uso do termo arte rupestre. Alguns autores têm adotado alternativas terminológicas, como: Registro rupestre (Pessis, 1993; Martin: 1997; Pessis e Guidon, 2000; Pessis et al, 2018), Registro gráfico ou Grafismo rupestre (Pessis, 2003; Cisneiros, 2010, 2017), Expressão rupestre (Soares, 2003) e Representação rupestre (Comerlato, 2005). Essas designações podem estar tanto ligadas ao conceito e linha de pesquisa trabalhados, ou mesmo a uma tradição no uso do termo. Para o presente trabalho será dotado o termo 'registro rupestre' cuja definição remonta à documentação arqueológica.

\begin{abstract}
O termo 'registro rupestre', definição que tenta substituir entre os arqueólogos a consagrada expressão 'arte rupestre', pretende liberar da conotação puramente estética algo que, seguramente, é a primeira manifestação artística do homem, ao menos em grandes áreas geográficas onde a arte móvel em pedra e osso não aparece anteriormente às gravuras e pinturas rupestres (Martin, 2013, p. 239).
\end{abstract}

Os conceitos adotados para o estudo dos registros rupestres na presente pesquisa tratam da identificação, da morfologia, da ocorrência, da integridade e da visibilidade das mesmas, nos 
sítios do Parque Nacional do Catimbau, sendo assim, será particularizada aqui a documentação gráfica dos grupos autores.

Investigadores de diversas áreas (História, Arqueologia e Antropologia) vem debatendo e tentando explicar a presença dessas manifestações gráficas em todos os continentes de diversas maneiras, passando desde hipóteses simplistas às mais complexas. Entre essas tentativas de explicação destacam-se: arte pela arte; totemismo e magia simpática, meio de comunicação entre outras.

Todos esses debates seguem sendo atuais. Porém, nenhuma dessas respostas isoladas é de fato satisfatória para explicar o conjunto dos registros rupestres. A principal causa dessa dificuldade segundo Gutierrez (2012) está no fato dos registros rupestres, terem origens cronológicas e espaciais diversificadas. Assim, a única maneira de interpretar corretamente esses vestígios passa pela adoção de um corpus metodológico que avalie os grafismos rupestres em relação ao seu contexto ambiental, cronológico e gráfico (Cisneiros et al, 2019).

Segundo Cisneiros et al (2019), é importante salientar que a maioria das tentativas de explicar as manifestações gráficas dos grupos pré-históricos foram condicionadas aos elementos cognitivamente reconhecíveis. Ou seja, as figuras que representavam de forma naturalista animais, homens e plantas, elementos do mundo sensível. Existe porém, um outro grupo de figuras, as chamadas simbólicas, geométricas ou grafismos puros, cujo acesso ao código gráfico não é tão simples. Essas figuras apresentam elementos cujo significado não está claramente estabelecido no mundo sensível. Esses elementos, por não serem reconhecíveis cognitivamente, ou seja, não terem correspondência direta com os elementos do mundo sensível, foram trabalhados como espécie de ideogramas ou pré-escrita.

A sistematização desse tipo de grafismos foi realizada por Sauvet (1990) para sítios europeus, que distinguiu conjunto de grafismos denominados ideomorfos ou esquemático-abstrato da seguinte forma:

1. Formas elementares (pontos, linhas retas e curvas);

2. Formas planas ou fechadas (triangulares, quadrangulares e circulares).

Os signos, segundo Sanchidrian (2018) adquirem distintas maneiras de levar a cabo as composições. O processo de agregação de formas elementares e planas terminam por dar lugar a signos mais complexos (Cisneiros et al, 2019). Ou seja as composições básicas desses grafismos a medida que se repetem se tornam complexas, assim observa-se: 
- duplicações (pares de elementos similares);

- alinhamentos (repetições sucessivas do mesmo signo) e

- alternância (espaço onde se alternam distintos elementos).

As figuras também podem apresentar-se complexas, para este o autor, que estabelece as seguintes distinções:

- embutido (uma figura dentro da outra),

- concatenado (série unida desse elemento as vezes por meio de uma forma elemental) e

- aproximado ( justaposição da mesma figura).

De igual modo, a organização do espaço através dos signos em campos disponível do suporte pode expressar segundo Cisneiros (2010) as simetrias estas estão ligadas tanto a repetição de padrões (alinhamento, alternância e duplicações) quanto a um efeito técnico de carimbo.

Ainda segundo Sanchidrian (2018:26), podem ser "considerados como ideomorfos (nome cunhado por esse autor para grafismos puros) todas las figuras geométricas o abstratas que no obtienen uma concordância com um sujeito real".

Ao analisar os grafismos rupestres, os pesquisadores costumam fazer uma classificação inicial apoiada na técnica de confecção dos grafismos, opondo principalmente pintura à gravura. Para Sanchidrian (2018), a presença dos grafismos puros (ou ideomorfos), poderia ser um indicativo de um objeto material, de acordo com a forma com que se apresentam na natureza:

a) Escutiforme: em forma de escudo;

b) Laciforme: em forma de laço (ou entrelaçado);

c) Tectiforme: pentágonos (ou linhas cruzadas) que remeteriam a um teto de cabana;

d) Claviformes: una clava (espécie de bastão);

e) Aviforme: em um formato próximo a de uma ave.

Uma outra tipologia de análise dos grafismos puros fora elaborada por Leroi-Gourhan (1979), distinguindo os traços finos (linhas abertas) dos grossos (que podiam delimitar áreas possivelmente representadas), onde os primeiros compreenderiam os elementos de desenho linear, tais como: traços retos, meandros, pontos, etc. e os outros, figuras geométricas que demarcavam superfícies fechadas, tais como círculos, quadrados, triângulos, etc. Aos mais simples, foi atribuído um sentido masculino, ao passo que aos mais complexos, atribuiu um sentido feminino. 


\section{Aportes metodológicos para o estudo dos grafismos rupestres no Brasil}

O primeiro trabalho apresentado para classificação dos registros rupestre na região Nordeste do Brasil, tendo por base o conceito de Tradição foi o de Valentin Calderón em 1970. Em sua classificação dos sítios de grafismos rupestres do sudeste da Bahia distinguiu duas tradições: Realista e Simbolista. A primeira identificada a partir de elementos reconhecíveis (figuras humanas e de animais) marcadas pelas ações que executam e pelo caráter dinâmico. A segunda definida a partir de elementos essencialmente geométricos com composições abstratas. Segundo Calderón (1983):

A Tradição Simbolista é a mais abundante e espalhada por todo o País. Geométrica ou grosseiramente figurativa, deve corresponder a povos marginais, com cultura muito primitiva. Encontramo-la na Caverna do Bode, na Serra Solta, no Rio São Francisco (Curaçá e Petrolina) e em diversos pontos da Chapada, especialmente nos sopés desta, perto da estrada que vai de Irecê a Morro do Chapéu. São sempre motivos isolados sem correlação aparente. Superpõem-se e misturam-se sem conservar nenhuma harmonia, variando bastante quanto à forma. Podem ser simples círculos ou espirais, assim como complicados desenhos lineares altamente elaborados como os que se podem ver na Serra Solta (Calderón, 1983: 15-16).

Faz-se importante salientar aqui que essa visão está em oposição aos grafismos figurativos, cuja temática era naturalista, expressando movimentos e harmonia. Pelas palavras do autor observa-se a ideia evolucionista de quanto mais harmônico e próximo ao orgânico, mais complexa e recente seria a sociedade (Cisneiros et al , 2019). Essa visão foi se modificando à medida que os sítios iam sendo escavados e as pinturas rupestres com características diferentes iriam ganhando cronologias relativas ou ante quen baseadas na superposição de painéis por sedimentos ou através de descobertas de placas pintadas no contexto estratigráfico.

O ordenamento preliminar, naquele momento da pesquisa, tinha caráter hipotético e fundamentava-se, sobretudo na constatação de que havia uma dominância numérica de tipos de figuras representadas nos painéis de pintura rupestre que apareciam com diferentes formas em espaços geográficos também distintos (Cisneiros, 2010).

Os primeiros critérios técnicos para o tipo de ordenação proposto foi baseado na taxonomia dos vestígios. Esse critério distinguia dois grandes grupos em relação ao plano tecnológico: grafismos pintados e grafismos gravados (Guidon, 1989 apud Cisneiros, 2008). 
O segundo critério utilizado referia-se ao reconhecimento que ofereciam os grafismos. Alguns permitiam conhecer elementos do mundo sensível enquanto outros eram sinais gráficos sem possibilidade de reconhecimento cognitivo (Pessis et al 2018). Dentro das figuras reconhecíveis foram identificadas duas classes de pinturas: uma, em que as figuras representavam pessoas e animais desenvolvendo ações e outra, em que as figuras representavam pessoas e animais em posição estática, sem o desenvolvimento de ação.

Assim, as tradições de registros gráficos foram definidas pelas classes de grafismos representados e pela proporção relativa que estas classes guardam entre si. O conceito de Tradição correspondia assim ao conceito de horizonte cultural ${ }^{1}$. O mesmo conceito era utilizado para segregar conjuntos de artefatos das indústrias de material lítico e cerâmico.

Considerando os aspectos acima descritos, Guidon (1981) classificou as pinturas da região Nordeste, tomando por base principalmente os Sítios da Serra da Capivara em: Tradição Nordeste, Agreste e Geométrica. Outras Tradições também foram acrescidas para a mesma região (Prous, 1992; Beltrão, 1994), tais como: tradição São Francisco e Tradição Astronômica (Quadro 1).

A partir do quadro sintético abaixo, é necessário considerar que nem todas as tradições apresentadas têm a mesma profundidade e sistematização de estudos. Dentre as tradições apresentadas a Tradição Nordeste, a Agreste e a São Francisco estão definida de forma mais precisa para a região, enquanto as tradições geométrica e astronômica seguem carecendo ainda de melhores aportes, assim como a tradição itaquatiara para gravura rupestre que abrange atualmente todos os sítios com gravuras. Aqui também considera-se que os grafismos puros estão distribuídos em todas as tradições, umas em menor proporção e integrados sobretudo à cenas, como é o caso da Tradição Nordeste e outros de forma mais dominante como na tradição Geométrica, Agreste e Astronômica.

\footnotetext{
1 O conceito de horizonte cultural em arqueologia corresponde ao conjunto de atributos culturais de um grupo humano relacionado com o espaço geográfico e restrito a uma faixa cronológica (Pessis, 1992).
} 
Quadro 1: Características preliminares das Tradições rupestres no Nordeste do Brasil para pintura.

\begin{tabular}{|c|c|c|}
\hline Tradição & Características preliminares & Autores principais \\
\hline Nordeste & $\begin{array}{l}\text { Identificada a princípio no estado do Piauí por e no Rio Grande do Norte } \\
\text { Pode ser caracterizada pela variedade dos temas representados } \\
\text { (antropomorfos, zoomorfos e fitomorfos) e pela riqueza de enfeites e } \\
\text { atributos que acompanham as figuras humanas. } \\
\text { O maior traço distintivo deste conjunto são as figurações naturalistas e } \\
\text { dinâmicas envolvidas em cenas cotidianas (dança, guerra, sexo) que são } \\
\text { habilmente representadas, utilizando a técnica de traços leves e seguros. A } \\
\text { presença de zoomorfos e antropomorfos se dá de forma bastante } \\
\text { equilibrada, e muitas vezes em associação e situações coletivas como caça, } \\
\text { coleta, cenas de bando. }\end{array}$ & $\begin{array}{l}\text { Guidon }(1975) \\
\text { Martin }(1982,2013) \\
\text { Monzon, (1982) } \\
\text { Pessis, }(1987 ; 2018) \\
\text { Prous (1992) }\end{array}$ \\
\hline Agreste & $\begin{array}{l}\text { Definida a partir dos sítios arqueológicos evidenciados nos estados de } \\
\text { Pernambuco e Piauí. Entre suas características principais podem ser } \\
\text { observadas a predominância de grafismos reconhecíveis, principalmente } \\
\text { antropomorfos geralmente dispostos de forma isolada. Os grafismos que } \\
\text { representam ações são raros e quando aparecem representam unicamente } \\
\text { cenas de caça com poucas figuras envolvidas. São comuns mãos, pintadas e } \\
\text { carimbadas. } \\
\text { Os grafismos puros são abundantes, representando morfologias diferentes e } \\
\text { diversificadas. Podem aparecer de forma bastante simples em linhas } \\
\text { paralelas, em ziguezague e círculos concêntricos ou em formas mais } \\
\text { elaboradas com linhas concêntricas e decorações labirínticas. }\end{array}$ & $\begin{array}{l}\text { Aguiar }(1986) \\
\text { Guidon }(1975) \\
\text { Martin }(1982 ; 2013) \\
\text { Amaral }(2015) \\
\text { Pessis }(1987 ; 2018) \\
\text { Prous (1992) }\end{array}$ \\
\hline $\begin{array}{l}\text { São } \\
\text { Francisco }\end{array}$ & $\begin{array}{l}\text { Identificada a princípio no estado da área do rio São Francisco nos estados da } \\
\text { Bahia, Alagoas e Sergipe. } \\
\text { Pode ser caracterizada pela dominância de grafismos puros. As } \\
\text { representações antropomórficas e zoomórficas são esparsas, e quando } \\
\text { aparecem são representados quase que exclusivamente por peixes e lagartos. } \\
\text { O maior traço distintivo deste conjunto são as figurações naturalistas e } \\
\text { dinâmicas envolvidas em cenas cotidianas (dança, guerra, sexo). A presença } \\
\text { de zoomorfos e antropomorfos se dá de forma bastante equilibrada, e muitas } \\
\text { vezes em associação e situações coletivas como caça, coleta, cenas de bando. }\end{array}$ & Prous (1992) \\
\hline Astronômica & $\begin{array}{l}\text { Identificada principalmente no estado da Bahia e ao longo do rio São } \\
\text { Francisco. } \\
\text { Essa tradição é particularmente dotada de um referencial relacionado ao seu } \\
\text { significado. Se caracteriza por apresentar círculos, pontos e linhas cuja a } \\
\text { associação as relacionam a eventos celestes como: cometas, lua, sol e } \\
\text { estrelas. }\end{array}$ & $\begin{array}{l}\text { Beltrão (1986) } \\
\text { Alemany (1986) }\end{array}$ \\
\hline Geométrica & $\begin{array}{l}\text { Identificada em conjunto heterogêneo, distribuídos em variados sítios e } \\
\text { contextos arqueológicos da região Nordeste. } \\
\text { Essa tradição foi identificada preliminarmente e caracteriza-se por apresentar } \\
\text { em sua maioria grafismos puros. Os grafismos de composição são pouco } \\
\text { numerosos. Podem aparecer sozinhos ou junto a painéis de outras tradições. } \\
\text { O tema dominante passa a ser os tridígitos. }\end{array}$ & $\begin{array}{l}\text { Guidon (1989) } \\
\text { Schimitz (1984) } \\
\text { Prous (1992) } \\
\text { Beltrão (1994) }\end{array}$ \\
\hline
\end{tabular}

Fonte: Cisneiros et al (2019). 


\section{Grafismos puros}

Quando se trata de grafismos puros ou abstratos, se faz menção quase que imediata às formas geométricas como representativas desses tipos de grafismos. Voltando às questões terminológicas, nem sempre se põe fácil definir um termo que seja isento de valorações ou problemas terminológicos (Cisneiros et al, 2019). Para evitar trabalhar com novas expressões e cair novamente em contradições epistemológicas, utilizar-se-á aqui o termo grafismos puro, já amplamente trabalhado e discutido nos estudos sobre registros rupestres no Nordeste do Brasil.

De fato há uma tendência desses grafismos representarem ou aludirem a um cenário geométrico de reconhecimento. Na história da arte é comum a utilização do termo geométrico para se referir às formas que poderiam ser geradas por métodos da geometria euclidiana, que se baseia em ponto, intermediação e congruência no espaço plano.

Os Grafismos Puros podem se apresentar na natureza sob a forma de figuras geométricas (retangulares, quadradas, triangulares) ou abstratas. Martin (2013), assinala que estes grafismos, comuns nos registros rupestres, podem se apresentar como espirais, círculos radiados com linhas paralelas, cruzadas e onduladas podendo indicar, dependendo do grupo cultural, símbolos cujo significado podem ter desaparecido com os autores. Assim, ficamos apenas com o significante gráfico. É a partir da análise desse significante gráfico que essa pesquisa se desenvolveu.

Um fator importante em ter em consideração, é que as formas geométricas fazem parte do desenvolvimento da humanidade e tem acompanhado os grupos humanos desde o alvorecer da espécie, seja em seu universo gráfico ou sob as formas construtivas dos artefatos. As formas geométricas são formas abstratas surgidas a partir da observação do entorno natural. Sobre as formas geométricas Bonell (2006) escreve:

As formas geométricas são formas ativas, orgânicas, acumulativas, são configurações com capacidade organizativas que provocam e movem a imaginação. São formas fundamentais que estão presentes desde a préhistória e são comuns a todos os grupos humanos (Bonell, 2006).

Assim, pode-se considerar as formas geométricas ou figuras geométricas elementares figuras abstratas simples, formadas normalmente por segmentos de reta, polígonos regulares ou linha como: quadrado, triângulos, equilátero e círculos. Estas são formas básicas universais que 
devido a sua qualidade, regularidade, simetria e generalização tem tido um transcurso na história da humanidade com ampla utilização funcional, especulativa e simbólica. Também se configuram em formas geométricas as formas regulares obtidas a partir do círculo, quadrado ou triângulo, e algumas outras, tais como pentágono e hexágono.

A definição de grafismos puros remete às representações rupestres que não permitem o reconhecimento cognitivo direto subjacente ao universo sensível. Este conjunto inclui os grafismos que geralmente são denominados na literatura sobre registros rupestres, como figuras geométricas ou abstratas (Pessis et al 2018).

Ao observar o conjunto de grafismos puros em um sítio pode-se assinalar que diante da liberdade criativa disponível a partir da união de elementos geométricos, nota-se no cenário rupestre certa restrição e recorrência de algumas imagens. São pontos que se repetem em sequência, círculos concêntricos e linhas paralelas ou intercruzadas.

Esse trabalho tem como objetivo principal observar essas recorrências em sítios com pinturas rupestres do Parque Nacional do Catimbau, especificamente no município de Buíque, analisando os modelos figurativos que se apresentam nesses sítios e como esses estão dispostos no espaço.

Os grafismos puros segundo Pessis (1984) podem fazer parte de uma composição na qual estão também presentes grafismos reconhecíveis, ou podem também ser os únicos elementos de um conjunto gráfico. Para análise das duas situações, a autora propõe:

1. Conjunto de grafismos puros e grafismos reconhecíveis - análise dos grafismos não pode ser desvinculada da análise dos grafismos reconhecíveis, pois o conjunto apresenta distribuição susceptível de ser interpretada. Em outras palavras, é provável que dentro desse contexto gráfico o grafismo puro tenha função ligada a dinâmica dos grafismos reconhecíveis (Figura 1).

2. Nos conjuntos homogêneos de grafismos puros - aqui o primeiro problema a considerar é o processo de segregação dos grafismos contidos no painel, isto é, como deve ser estabelecida a unidade gráfica. A ausência de reconhecimento muitas vezes impede o seccionamento de unidades de significantes. Aqui é necessário por em uso o espaço contornado e delimitado da figura (Figura 2). 
Pode-se dizer que há na região do Parque do Catimbau um predomínio quantitativo das formas geométricas frente aquelas que podem ser reconhecidas ou claramente identificadas, como seriam os antropomorfos e zoomorfos. Essas formas geométricas cobrem as superfícies disponíveis dos abrigos $\mathrm{cm}$ repetidos motivos. Em algumas ocasiões porém essas figuras se misturam a grafismos reconhecíveis como se pertencessem a cena, fazendo com que o observador faça cognitivamente a associação desses elementos a uma ação que se desenvolve mesmo sem ter os elementos totais de reconhecimento.

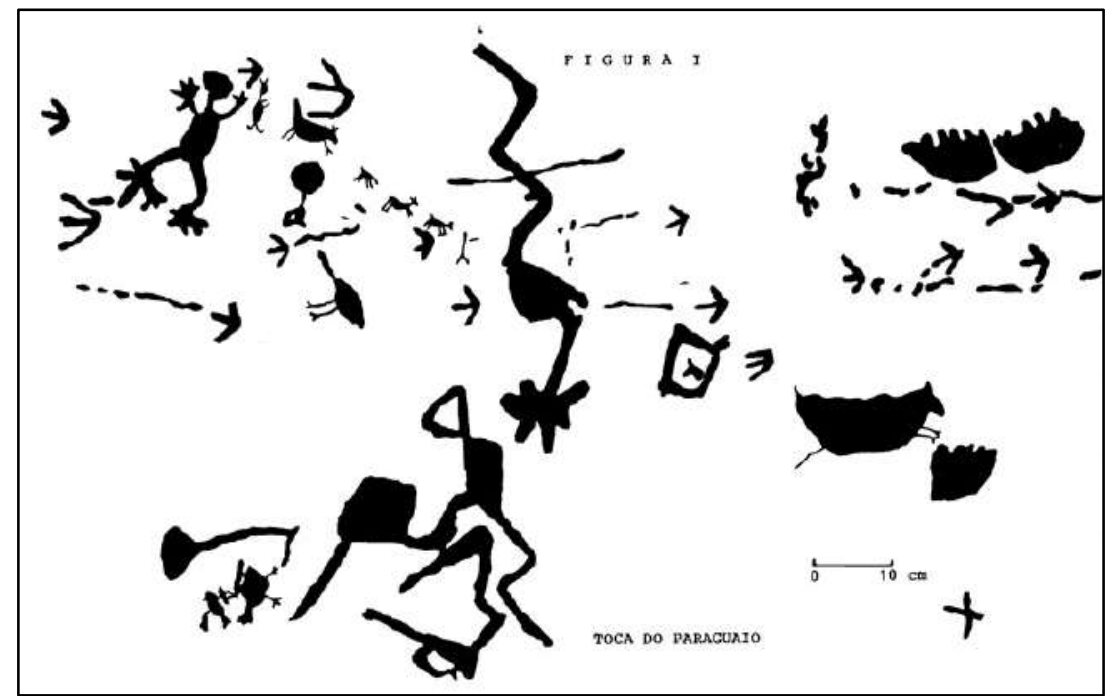

Figura 1: Conjuntos de grafismos puros e de grafismos reconhecíveis. Fonte: Pessis, 1992.

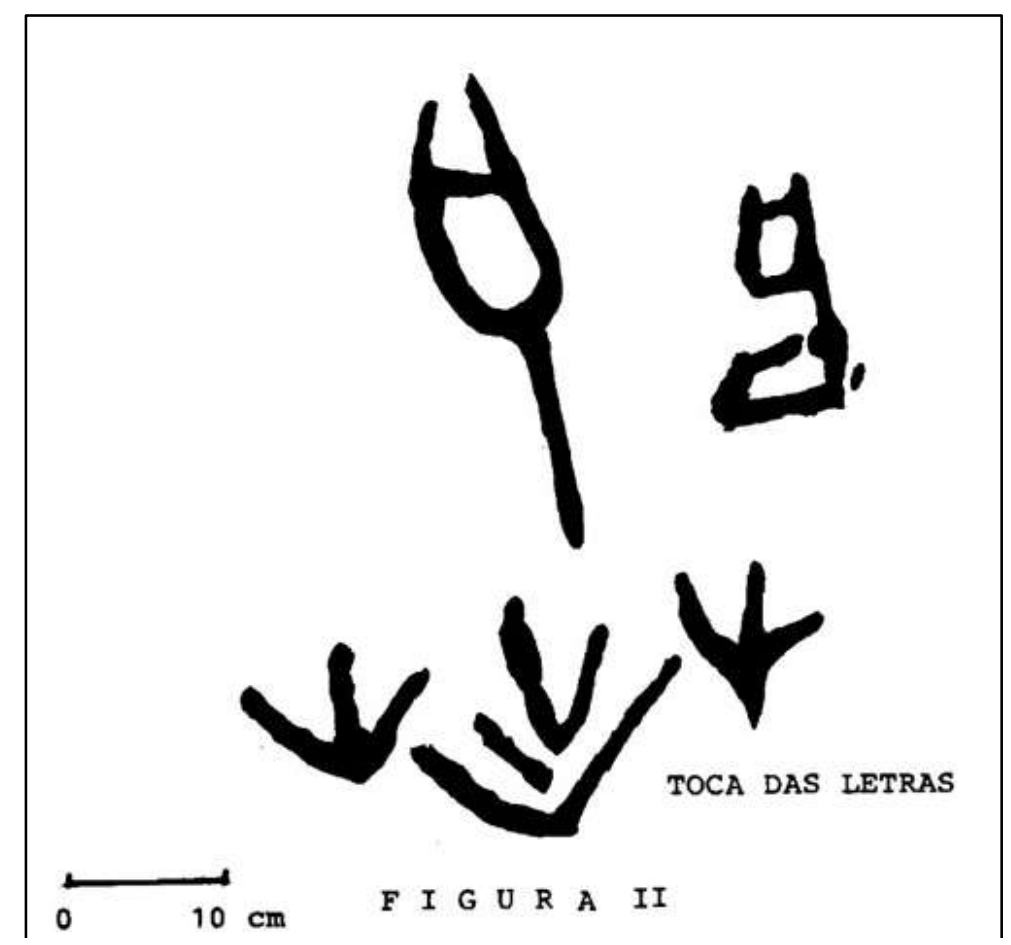

Figura 2: Conjuntos homogêneos de grafismos puros. Fonte: Pessis, 1992 


\section{Método}

Esta pesquisa tem por proposta a análise e caracterização dos grafismos puros do Parque Nacional do Catimbau. O Parque que está situado na região Agreste de Pernambuco e contém 64 (sessenta e quatro) sítios arqueológicos com grafismos cadastrados no CNSA (Cadastro Nacional de Sítios Arqueológicos) do Iphan (Instituto do Patrimônio Histórico e Artístico Nacional). Para o presente trabalho, dos 26 (vinte e seis) sítios identificados no município de Buíque, foram segregados 15 (quinze) sítios por estarem esses grafismos em situação de boa visualização no painel e por sua complexidade gráfica.

Com a finalidade de sistematizar as informações acerca dos sítios, foi elaborado um protocolo a ser aplicado de maneira sistemática a todos os sítios pesquisados. Esse protocolo dispõe de descritores contextuais do ambiente onde se localiza o sítio e descritores gráficos em relação as pinturas rupestres. Assim, foram considerados os seguintes descritores: localização, suporte rochoso e grafismos rupestres.

- Localização do Sítio: Refere-se a identificação e localização do sítio, para isso foi considerado: nome, topônimo, município, coordenadas (UTM) e cota altimétrica;

- Suporte Rochoso: refere-se as características do suporte onde foram realizadas as pinturas: tipo do sítio (matacão, abrigo, céu aberto), comprimento, largura, orientação, rocha suporte, área abrigada.

- Grafismos Rupestres: Refere-se aos grafismos rupestres identificados no sítio: tipo de execução do grafismo, área pictórica, figuras (reconhecíveis/não reconhecíveis), composição do painel, sobreposição.

A segregação dos grafismos puros estudados se deu mediante o reconhecimento da sua integridade, ou seja, só foram selecionados para análise os grafismos puros completos (Figura 3 e 4). A Integridade refere-se a área visível do grafismo puro a olho nu, medida em porcentagem visível e possibilidade de contextualização. 


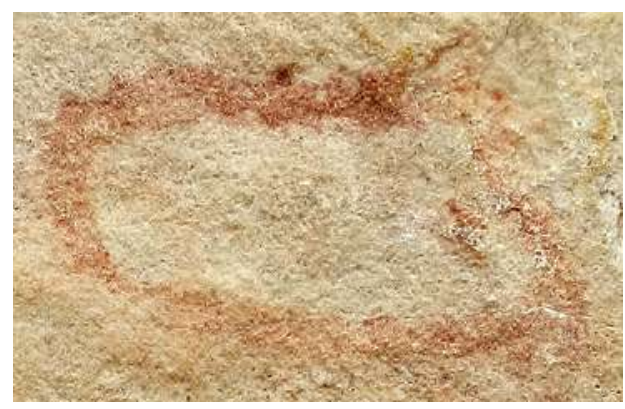

Figura 3: Grafismos puro simples - formado por apenas um traço executável. Sítio Macambira Buíque - PE

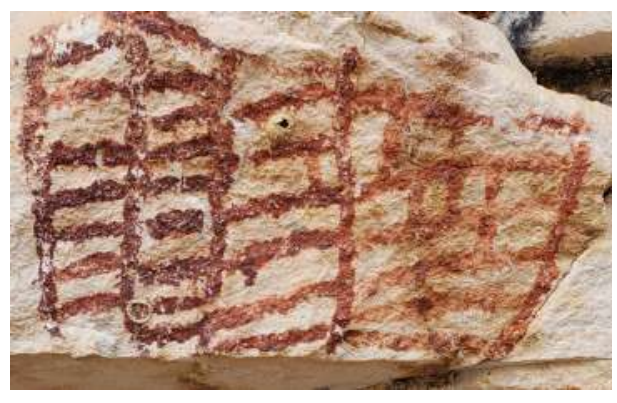

Figura 4: Grafismos puros complexos formado por variadas linhas e pontos intercruzados. Sítio Alcobaça - Buíque - PE.

A presente pesquisa está inserida dentro da perspectiva de estabelecimento inicial de padrões morfológicos para os Grafismos Puros para área, para que a posteriori, possam ser realizadas a identificação de elementos gráficos e caracterizações mais particulares. Desta forma, a coleta de informações e a sistematização dos dados obtidos em laboratório e em campo foram organizados com a criação de parâmetros, com a finalidade de agrupar os grafismos puros dos sítios.

Para a realização desta pesquisa foram trabalhadas para a identificação e contexto dos grafismos puros e as seguintes variáveis: Morfologia, Composição, Cor e Técnica.

A morfologia pode ser entendida basicamente como o estudo das formas externas de algo, podendo ser resumida, para este trabalho, no estudo da forma, do aspecto e da aparência do grafismo no suporte rochoso do Parque do Catimbau; A Composição diz respeito a associação dos mesmos, se estão visíveis nos painéis rupestres em formas isoladas ou compostas com outras representações, se estão retratados com preenchimentos ou vazados (vazios). A Coloração refere-se a presença de uma ou mais cores em sua confecção (presença de pigmentos) e a Técnica, que leva em consideração a forma que fora confeccionado o grafismo, baseado em critérios elencados por Sanchidrian (2018), que levam em consideração as formas técnicas aditivas, onde se avalia o desenho, a pintura e os traços.

Dentro do processo de segregação imagética laboratorial dos grafismos puros encontrados nos sítios, os mesmos foram estudados de acordo com seu contexto arqueológico e como estas representações podem ser enquadradas dentro dos cinco parâmetros elencados na tabela acima. A identificação de eixos de similaridade e diferenças destes registros arqueológicos, também foi valorado. 
Assim, o presente trabalho procurou identificar as morfologias gráficas dominantes entre os grafismos puros da área do Parque Nacional do Catimbau, reunindo-os em grupos por suas semelhanças tipológicas.

\section{Contexto Ambiental e Arqueológico do Vale do Catimbau}

O Parque Nacional do Catimbau, em Pernambuco, configura-se como o único Parque Nacional de Pernambuco. Se destaca no cenário brasileiro como uma das unidades de conservação do bioma da Caatinga, graças a sua extensa área, com cerca de 62.294,14 hectares distribuídos pelos municípios de Buíque (12.438 ha.); Tupanatinga (23.540 ha) na Microrregião do Vale do Ipanema, e Ibimirim (24.809 ha) na Microrregião do Moxotó do Estado de Pernambuco, assim como pela relevância do seu patrimônio arqueológico (Figura 5).

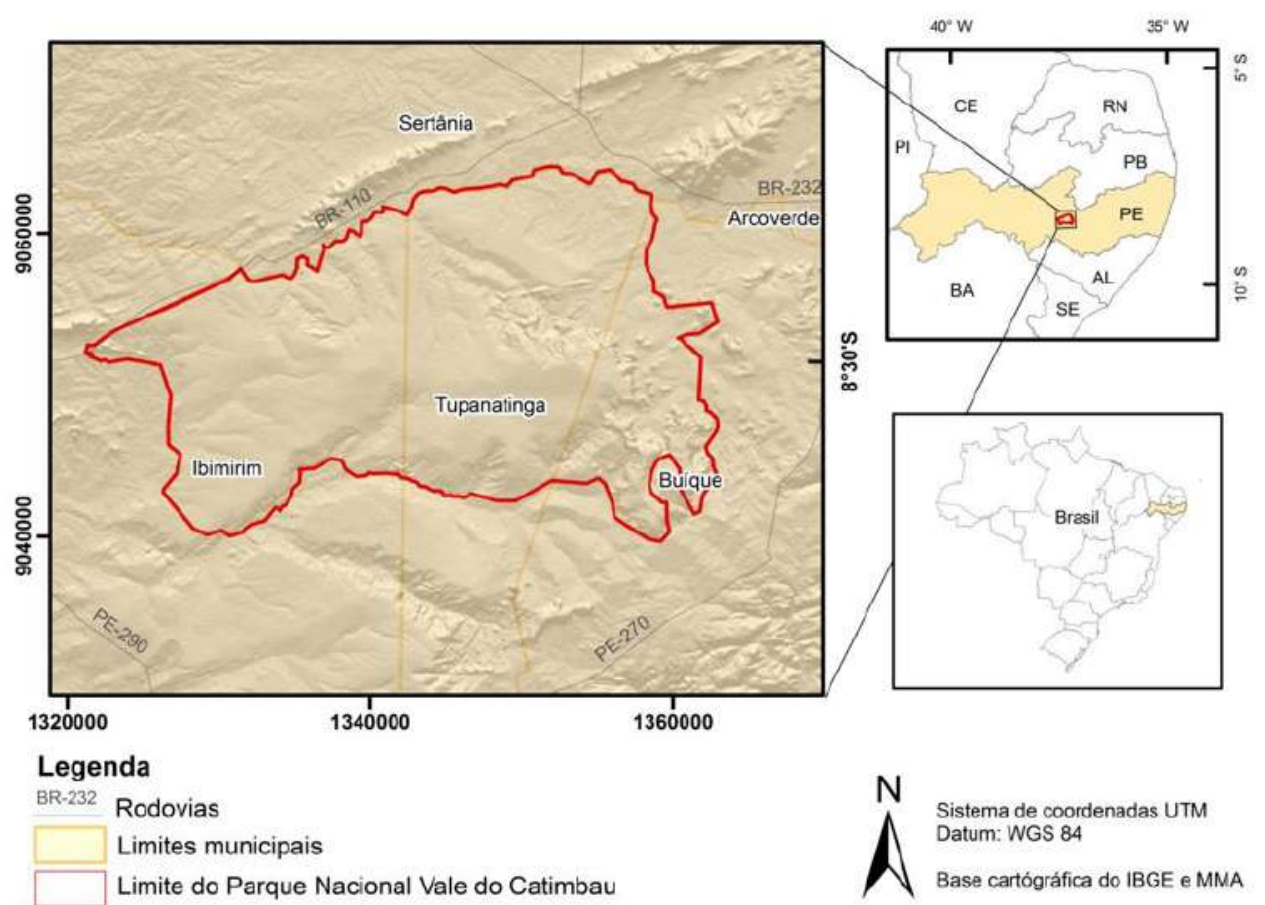

Figura 5: Localização do Parque Nacional do Catimbau. Fonte dos dados: IBGE (Instituto Brasileiro de Geografia e Estatística) e MMA (Ministério do Meio Ambiente). Elaborado por Rezende, 2016.

Em sua feição geológica, o Parque possui unidades que integram o embasamento précambriano, com bacias sedimentares do início do Paleozoico e afetadas no Mesozoico, além de coberturas cenozoicas ao norte, separadas pelo Lineamento Pernambuco, estrutura tectônica que corta o estado de leste a oeste. Os sedimentos que compõem estes depósitos integram a bacia do Recôncavo Tucano-Jatobá, com a área de estudo localizada no setor nordeste-leste 
desta estrutura morfoestrutural geológica, fora da bacia sedimentar do Jatobá e rodeado pelo embasamento cristalino do Planalto da Borborema (Correa et al, 2015).

No contexto geomorfológico, o Parque está inserido no Planalto Sedimentar da Bacia Jatobá, com altitudes que variam de 350 a 1100 m, na porção Sudeste do Catimbau. Ocorrem ainda a presença de estruturas homoclinais, resultantes de camadas superpostas, levemente inclinadas, numa direção constante. Esse tipo de disposição, geralmente corresponde à porção que circunda a zona central plana de uma bacia sedimentar. Desenvolve-se em rochas estratificadas de diferentes resistências e caracteriza-se pela associação de duas vertentes denominadas reverso e front.

$\mathrm{Na}$ área do Parque, podem ser observadas três macro-formas de diferentes características e distintas na paisagem: os arcos, os abrigos sob-rocha e as grutas. Os arcos mostram a baixa suscetibilidade do arenito em resistir à erosão pluvial e a eólica. A macro-forma mais abundante no Parque são os abrigos nos paredões areníticos, que possuem um desenvolvimento horizontal, com pequenos desníveis. Suas dimensões vão de 20 a $40 \mathrm{~m}$ de comprimento e de 2 a $5 \mathrm{~m}$ de profundidade. É nesses locais que estão a maior parte dos vestígios arqueológicos assim como também as pinturas rupestres (Ibama, 2002) (Figura 6).

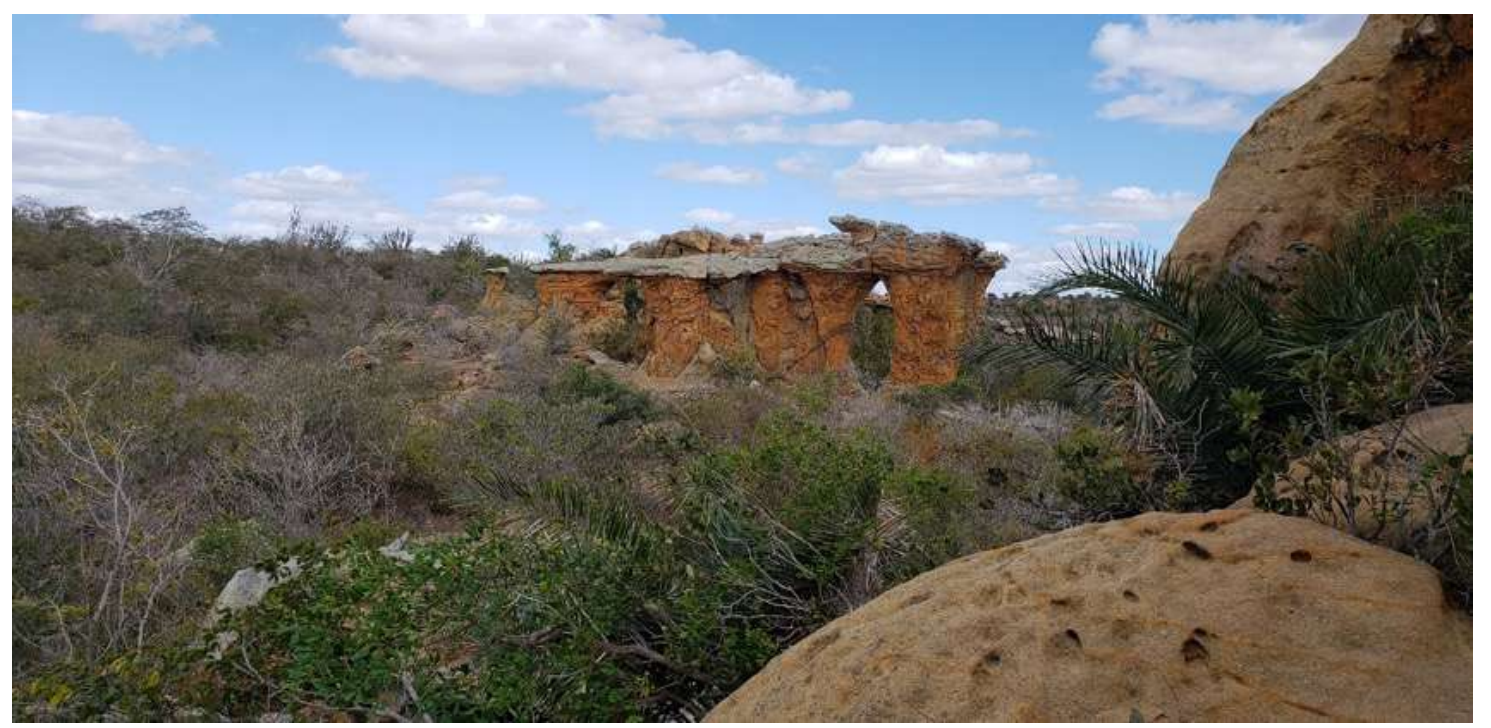

Figura 6: Uma das macro-formas geomorfológicas do Parque Nacional do Catimbau. Autor: Anderson Luiz, 2018.

A área de estudo compreende uma das maiores concentrações de sítios arqueológicos documentados e observados com temáticas gráficas, equivalendo-se em relevância comparada a Área Arqueológica da Serra da Capivara (PI) e área Arqueológica do Seridó (PB e RN), que 
possuem as duas maiores concentrações de sítios arqueológico do Nordeste e as mais estudadas até momento. $\mathrm{O}$ conjunto de sítios arqueológicos de uma área é integrante de um "acervo patrimonial" dos grupos humanos que por ela transitaram (seja de passagem ou ocupação) e são lugares ímpares e, de acordo com os usos, definidos a partir dos grafismos arqueológicos e agregado de elementos significativos e intrínsecos ao local (Proença, 2010).

As primeiras pesquisas arqueológicas na região ocorreram no ano de 1970, sob a coordenação das pesquisadoras Gabriela Martin e Alice Aguiar que selecionaram cerca de 20 sítios do Agreste de Pernambuco, nos seguintes municípios: Brejo da Madre de Deus, Taquaritinga do Norte, Alagoinha, Venturosa, Pedra, Paranatama, Brejinho, São Bento do Una e Passira (Correia, 2016). O intuito principal da pesquisa era levantar um panorama inicial das pinturas rupestres da região que possuíssem características semelhantes e recorrentes, traços típicos da Tradição Agreste, já considerada cronologicamente posterior a Tradição Nordeste, dentro da literatura arqueológica e já amplamente discutido em diversas publicações (Martin, 2013).

Estudos realizados até o momento sobre os grafismos da área apontam para uma grande variedade cultural, com o desenvolvimento de técnicas gráficas em diferentes áreas na mesma região de estudo; essa variedade também pode ser observada com a análise do material lítico e cerâmico. Essas análises vem fornecendo um extenso material (fichas de campo, fotografias, croquis, datações, perfis tecnológicos, dentre outros) que pode servir como referência no estudo dos componentes picturais da área em questão, podendo ser complementado por propostas de classificação destes registros rupestres, baseados "na similaridade e nos graus de complexidade dos desenhos" (Pessis, 1994).

Atualmente se tem considerado para a área as datações arqueológicas obtidas em torno de 6.000 anos B.P. Segundo Martin (2013) para o sítio Peri-Peri, no município de Venturosa, as datações são de $1.760 \pm 160$ anos B.P; e para o sítio Pedra do Tubarão com $2.030 \pm 50$ anos B.P, "obtidos a partir de fragmentos de ocre, misturados com matéria orgânica, com marcas de raspagem e pequenos recipientes em que se teria preparado o pigmento" (Martin, 2013: p. 28).

Em Oliveira (2001) é apresentada uma coluna cronoestratigráfica, da ocupação humana com datações entre $4.851 \pm 30$ anos B.P e $888 \pm 25$ anos B.P, e pesquisas arqueológicas realizados por Albuquerque \& Lucena (1987) no Sítio PE 91 - Mxa, na reserva particular 'Paraíso 
Selvagem', obteve a datação de $6.640 \pm 95$ anos B.P, a mais antiga para a presença humana no Vale do Catimbau.

Para o Sítio Alcobaça, no município de Buíque, foram obtidas as seguintes datações: $1.785 \pm 49$ anos B.P e $1.766 \pm 24$ anos B.P. Infelizmente essas datações não têm vinculação direta com os grafismos rupestres, embora venham a contextualizar cronologicamente a ocupação da área.

Ainda sobre os estudos na área do Parque, Amaral (2015) aponta que, para se definir a Tradição Agreste, foi necessário definir um critério inicial divisional: a existência de dois grupos de grafismos: os reconhecíveis e os não-reconhecíveis (ou puros), que aparecem isoladamente ou em conjunto com os registros gráficos dos sítios do Parque e os que foram listados nesta pesquisa. Para Martin (2013), as principais características de identificação desta tradição é ter a presença dos "grafismos puros labirínticos ou em forma de grades, espirais e linhas sinuosas de vários tamanhos e que, aparentemente, não guardam nenhuma relação entre si, são também elementos que nos levam a identificar as pinturas rupestres da Tradição Agreste" ( $p$. 274), com predominância de tons em vermelho e outras tonalidades (amarelo, preto), em menor escala.

\section{Análise - Grafismos Puros no contexto Parque Nacional do Catimbau}

Para a análise dos grafismos puros partiu-se de algumas variáveis relacionadas ao significante gráfico. Destas variáveis, as que mais possibilitaram o reconhecimento de recorrências e similaridades foram a morfologia dos grafismos e a técnica de fabricação dos mesmos.

Partindo da premissa que os grafismos puros apresentam conteúdo simbólicos, ou seja, um conjunto de ideias sob significantes abstratos, partiu-se nessa pesquisa da hipótese que existe uma regularidade nas formas desses grafismos na área de estudo. Isso, porém, não significa dizer que os grafismos são padronizados no sentido de serem todos totalmente similares. 0 que parece haver é uma tendência a repetição de algumas formas, embora nestas não seja prioritário a sua forma espelhada. Ou seja, não existe uma figura igual a outra e sim similaridades em formas. A exemplo círculos concêntricos; formas carimbadas, quadrangulares e retangulares formado por linhas paralelas.

Nos 15 (quinze) sítios arqueológicos distribuídos nos municípios de Buíque, foram estudados 84 (oitenta e quatro) grafismos puros, distribuídos conforme o gráfico abaixo. A escolha dos 
grafismos como já mencionado acima, foi atribuída a complexidade de traços e o grau de visibilidade atual que este apresenta (Gráfico 1 ).

Gráfico 1: Distribuição dos grafismos conforme os sítios estudados.

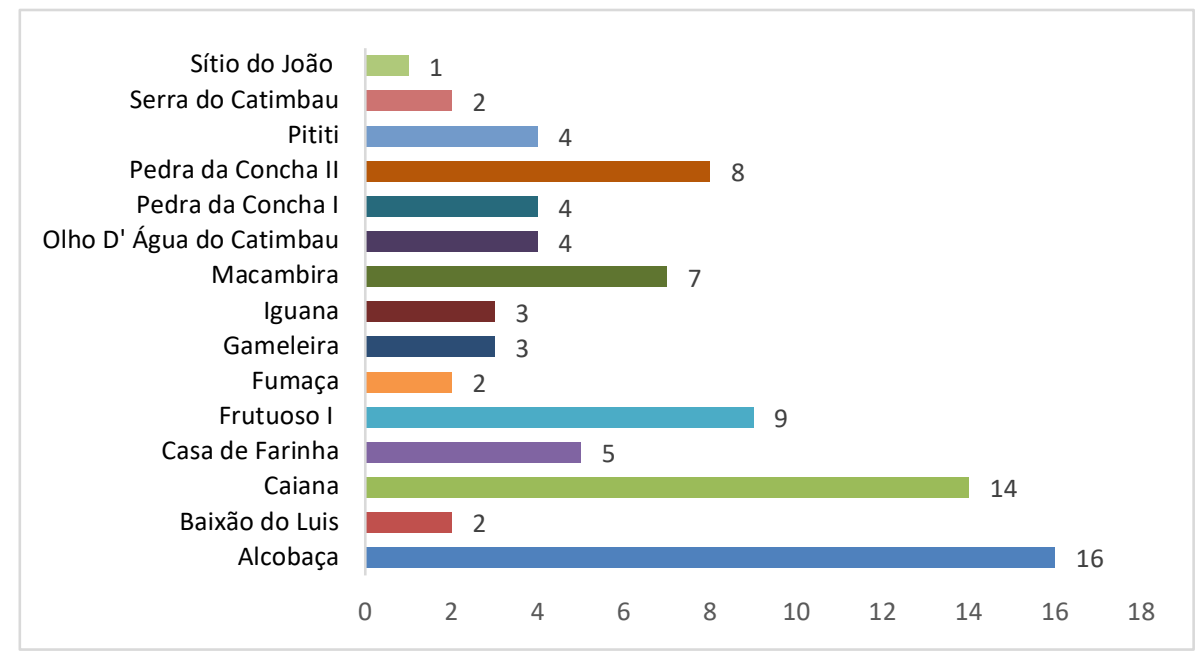

Dentro dos limites do Parque, na relação grafismo - suporte, observou-se que todos os sítios estudados são abrigos sob rocha, essa mesma uniformização está representada também no que tange a matéria-prima dominante, onde para todos os suportes dos sítios estudados foi constatado o arenito como litologia dominante. Essa homogeneidade está relacionada diretamente com a configuração geomorfológica da área.

Em relação ao agenciamento no espaço foi observado que dos 15 (quinze) sítios estudados para esse trabalho a maior parte deles, 10 (dez) estão localizados em média vertente, 3 (três) em alta e 2 (dois) em baixa vertente, distribuídos conforme mapa hipsométrico (Figura 7).

Com a aplicação dos parâmetros e variáveis desenvolvidos neste trabalho para os grafismos puros dos sítios em questão, foram identificados diversos pontos divergentes e convergentes entre os sítios, baseado na análise da cenografia e da técnica. 


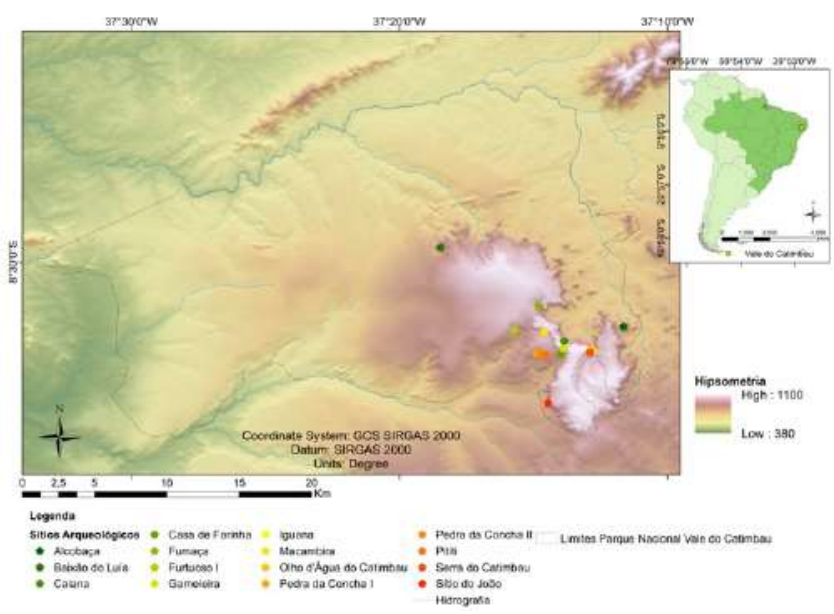

Figura 7: Mapa Hipsométrico do PARNA do Catimbau, apresentando a localização dos sítios pesquisados. Integridade

A longevidade das pinturas em um painel depende do agenciamento de vários elementos estruturadores do suporte como composição, porosidade, permeabilidade da rocha e das condições do ambiente onde este se localiza. Os sítios arqueológicos possuem um processo contínuo e dinâmico e as pinturas rupestres estão também sujeitas a esse processo (Cisneiros, 2019).

Segundo Pessis et al (2017), o intemperismo biológico, químico e físico atua como agente de degradação do suporte e consequentemente dos grafismos. Nos sítios estudados os agentes químicos têm atuado com maior intensidade entre eles os sais minerais que recobrem as pinturas.

O intemperismo e ações antrópicas atuantes sobre os suportes rochosos terminam por destruírem os exemplares rupestres, prejudicando assim a análise do conjunto total dos grafismos e sua atuação no espaço gráfico (Figura 8). Assim, foram destacados para a amostragem analisada 84 (oitenta e quatro) grafismos que configuravam-se entre os que apresentavam a totalidade de integridade morfológica, cujo desgaste visual não comprometese sua visualização completa (Quadro 2).

Foi observado nos sítios analisados que os maiores problemas que sofrem esses sítios são de ordem físico-química, embora por estarem localizados em área de proteção muitos sítios têm sofrido vandalismo como o sítio Pedra da Concha I e Olho d’água do Catimbau. O primeiro com seu painel principal totalmente destruído por aplicação de tinta óleo. 


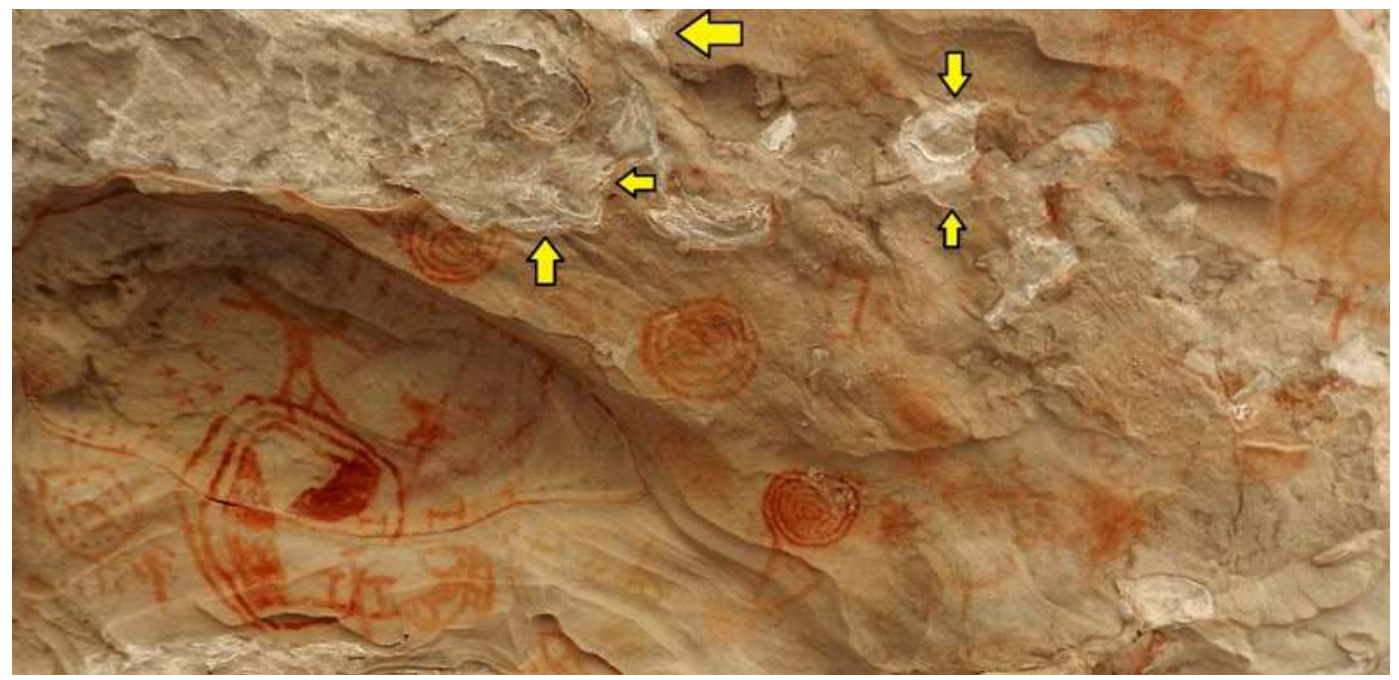

Figura 8: Exemplo de desplacamento do sítio Caiana, Buíque - PE. Configura-se na perda de muitas figuras existentes no suporte. Fonte: Laboratório de Registros Gráficos, Departamento de Arqueologia, UFPE.

Quadro 2: Parâmetros de Integridade.

PARÂMETROS DE INTEGRIDADE
$100-75 \%$
CATEGORIAS
(Grafismo puro retangular, Sítio
Alcobaça, Buíque - PE)
75 - 50\%
(Grafismo puro circular, Sítio Casa
de Farinha, Buíque - PE)
50 - 25\%
25 - 0\%
(Grafismo puro retangular, Sítio
Olho D`água do Catimbau, Buíque -
(Grafismo puro quadrangular, Sítio
Gameleira, Buíque - PE)




\section{Composição}

No parâmetro de composição, foi analisada a questão da presença e representação do mesmo no painel gráfico ou no contexto do sítio arqueológico, bem como se está representado graficamente isolado ou em composição com outros grafismos.

Lembrando que essa composição diz respeito a estarem compostos com outros grafismos puros ou de forma isolada, pois para esse trabalho foram selecionados apenas os grafismos puros que estavam isolados em conjuntos formados unicamente por grafismos puros

Esses grafismos completos não se apresentam de forma isolada nas manchas gráficas e a maior parte deles, 66 (sessenta e seis), estão em composição com outros grafismos puros complexos. Existe uma tendência desses grafismos estarem em composição, pois a coexistência deles é nitidamente visível, mostrando uma diversidade técnica e uma tencionalidade a representar, em um mesmo "locus", grafismos diferenciados.

Cor

Em relação à cor do pigmento e a utilização de variações cromáticas nos sítios estudados, a cor foi trabalhada como elemento cenográfico e não como componente técnico na composição do pigmento.

Os grafismos puros analisados no Parque Nacional Vale do Catimbau possuem dominância da coloração vermelha e amarela. A grande maioria dos grafismos tem contorno em pigmentos de coloração vermelha, que varia em tons desde o vermelho claro (observado nos sítios) até o vermelho escuro (Gráfico 2). Não foram realizadas para área análises de composição das tintas, infere-se porém, a despeito de algumas publicações que sua composição básica é obtida da hematita (óxido de ferro $-\mathrm{Fe}_{2} \mathrm{O}_{3}$ ), pigmento avermelhado, e a goetita (óxido de ferro hidratado - $\mathrm{FeO}[\mathrm{OH}])$, que fornece a coloração amarela e que o carvão ou a queima de ossos poderia fornecer o único pigmento preto de origem orgânica.

O que se observa na amostragem é a mesma dominância da cor vermelha, provavelmente confeccionada a partir da hematita. Essa dominância não é apenas verificada no conjunto de grafismos puros, essa cor é dominante para todos os grafismos da área, e o grafismo puro segue a mesma tendência. 
Gráfico 2: Distribuição dos grafismos conforme a cor do traço.

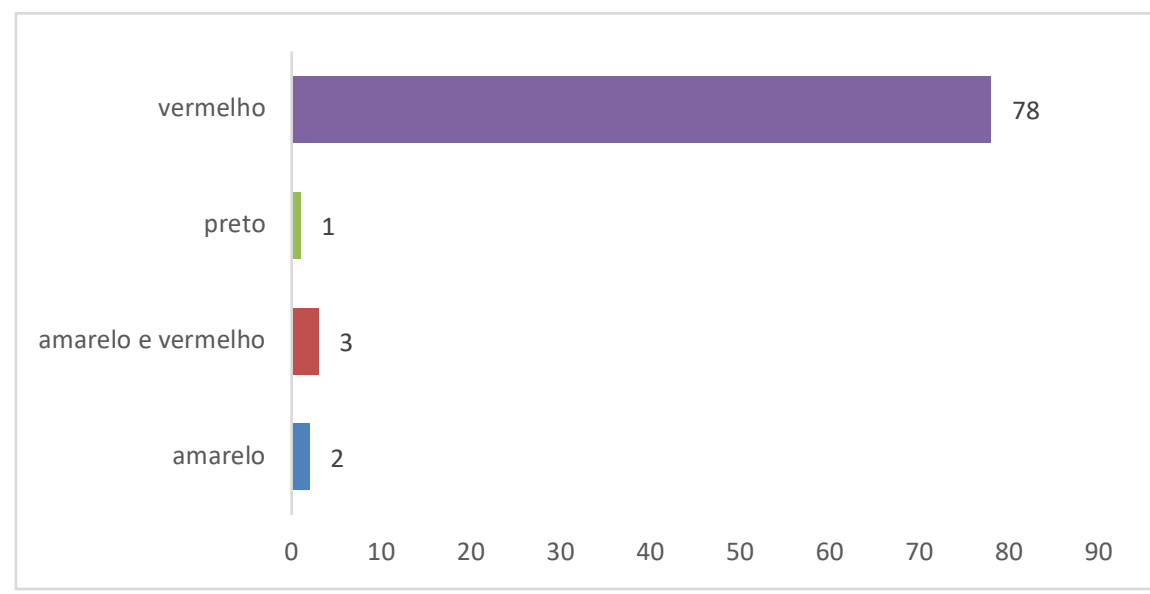

Morfologia

Dentro dos parâmetros morfológicos aplicado, procurou-se trazer uma abordagem aos grafismos, próxima aos conceitos geométricos atuais, para ajudar na possível apreensão e compreensão do mesmo, sem Ihe atribuir significado atual (haja vista a impossibilidade), apenas traçando paralelos entre os registros rupestres e as representações geométricas, pois o mundo real está repleto de formas, que podem representar um senso estético, aspectos práticos, sociais e econômicos do cotidiano, eventos astronômicos, dentre outros, que por sua vez, podem ser recorrentes nos sítios pesquisados. As formas foram agrupadas em categorias, para melhor entendimento (Quadro 3) (Gráfico 3).

Gráfico 3: Distribuição das categorias morfológicas.

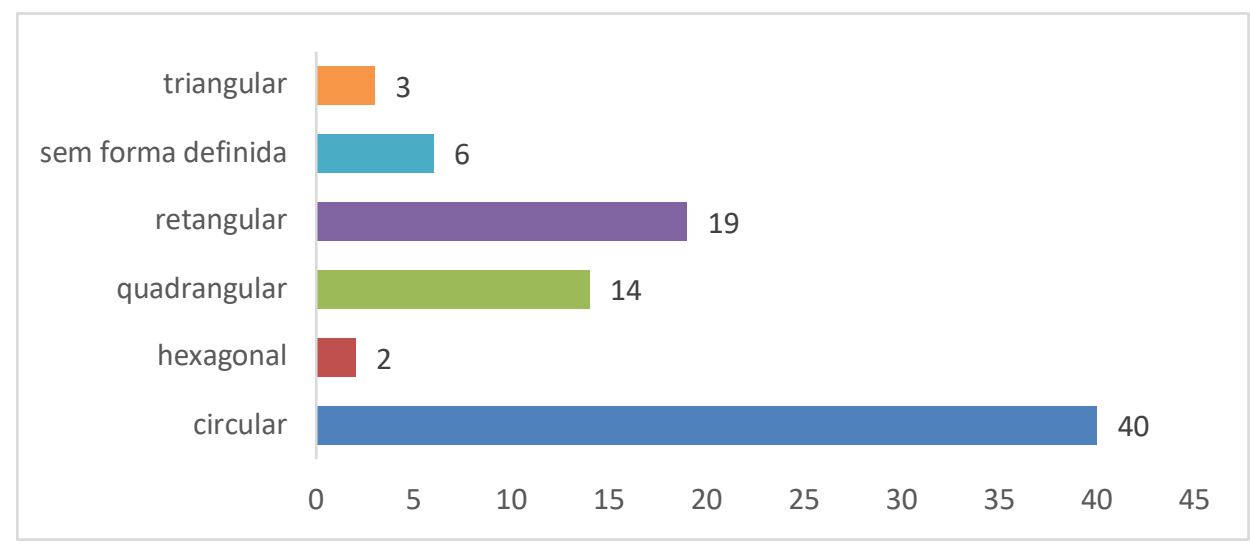

Observa-se em relação a morfologia que mesmo apresentando características morfológicas similares, as imagens de grafismos puros não são iguais, não existindo nos sítios analisados grafismos idênticos. 
Quadro 3: Parâmetros morfológicos.

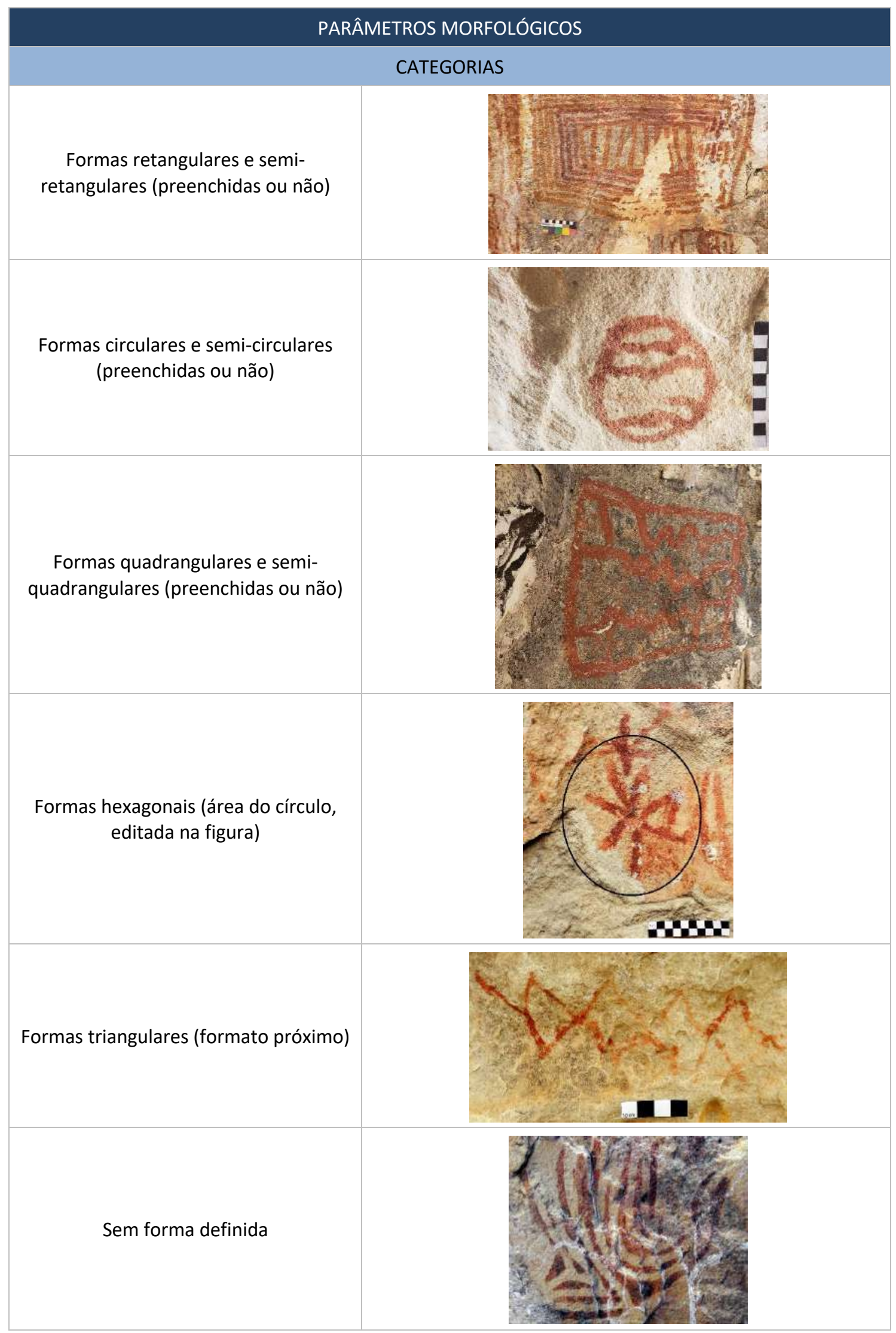


Ainda em relação a morfologia, algumas pinturas apresentaram linhas de contorno que as delimitavam e em outras essas linhas eram ausentes, deixando que o espectador delimite 0 cenário pictural.

\section{Preenchimento}

O preenchimento dessas figuras também foi um ponto de análise, seja com preenchimento interno ou sem preenchimento, provoca um efeito visual sobre o observador, ao contemplar a pintura. Esse efeito visual faz com que os grafismos puros, mesmo em localizações distais da mancha gráfica, ao serem identificadas se destaquem sobre as outras (Gráfico 4) (Quadro 4).

Segundo Cisneiros (2008): É o agenciamento gráfico com os traços essenciais e o conteúdo do universo simbólico do receptor que remetem ao reconhecimento ou ao não reconhecimento da imagem. A aparência de um objeto em particular não é sempre a mesma, e um espécime individual não se parece exatamente com os outros membros da mesma espécie.

Gráfico 4: Preenchimento interno dos grafismos

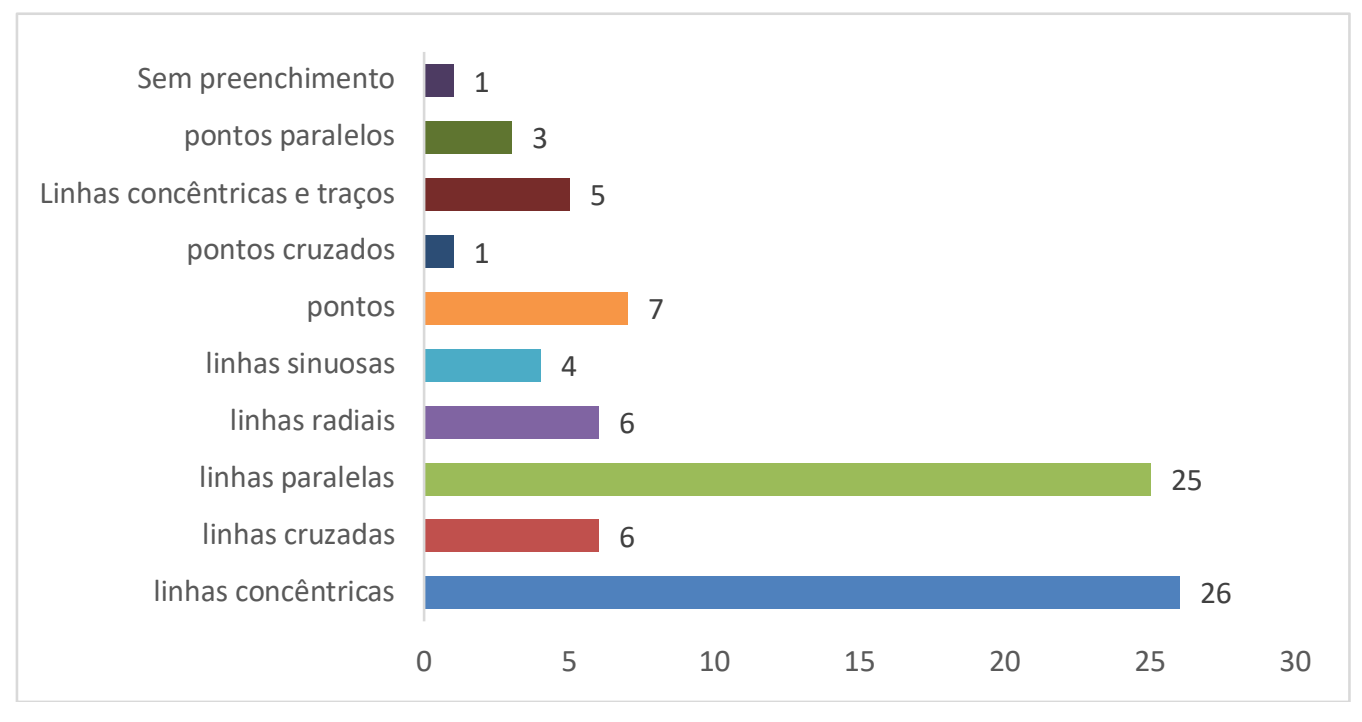

Observa-se em termos do preenchimento que esses integram os grafismos em sua unidade. Poucos grafismos são vazados e existe uma dominância na associação de técnicas mistas de preenchimento.

Observou-se também na amostra alguns grafismos formados por linhas sinuosas que poderiam ser confeccionados como espécie de "carimbos", esses grafismos possuem uma delimitação de seu espaço gráfico bastante preciso. 
Quadro 4: parâmetros de preenchimento

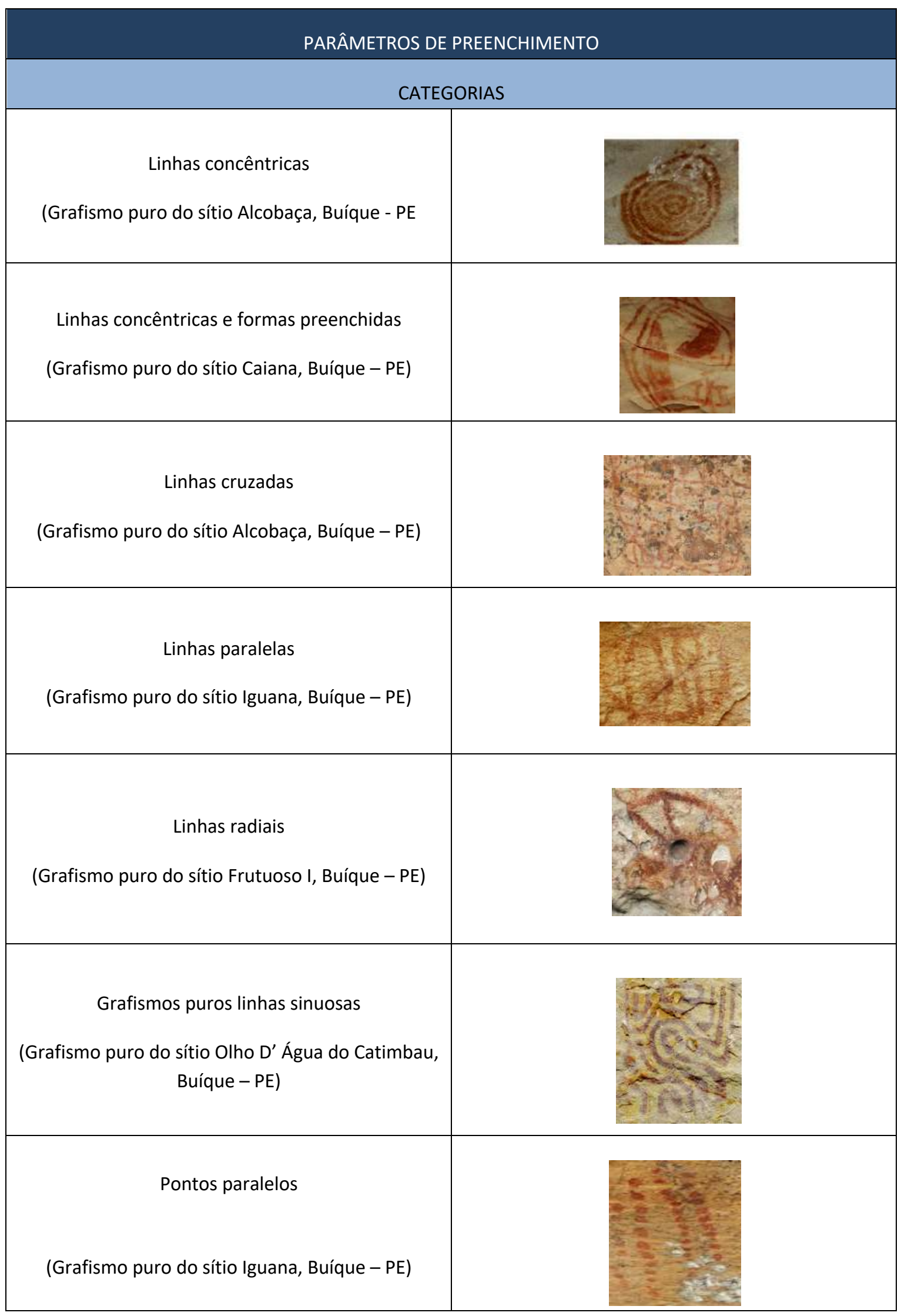




\begin{tabular}{|c|c|}
\hline Pontos cruzados & \\
(Grafismo puro do sítio Casa de Farinha, Buíque - \\
PE)
\end{tabular}

Técnica

O último parâmetro a técnica de caracterização dos grafismos puros da área de pesquisa levou em consideração a forma que fora realizado o grafismo, de acordo com os critérios elencados por Sanchidrian (2018), que leva em consideração as formas técnicas do traço, contínuo, descontínuo, modelalado e digitado.

Quanto a técnica do tipo do traço foi observado na amostra analisada os traços contínuos, descontínuos e digitados. Observou-se que o traço contínuo é dominante. Embora dominante observa-se que esse traço não é simétrico, não existe uma intenção simétrica nas linhas, que ora se apresentam mais finas ou mais grossas ao longo do traçado. Em algumas imagens é possível notar que foi utilizado o dedo como ferramenta pictural. Outra caraterística dentro da amostra estudada foi a de apresentar a técnica do digital, muitas unidades gráficas foram estudadas utilizando essa técnica, que não é muito comum nos grafismos rupestres no nordeste brasileiro em cenários tanto de grafismos reconhecíveis quanto não reconhecíveis.(Gráfico 5) (Quadro 5). 
Gráfico 5: Distribuição dos grafismos puros em relação ao tipo de traço

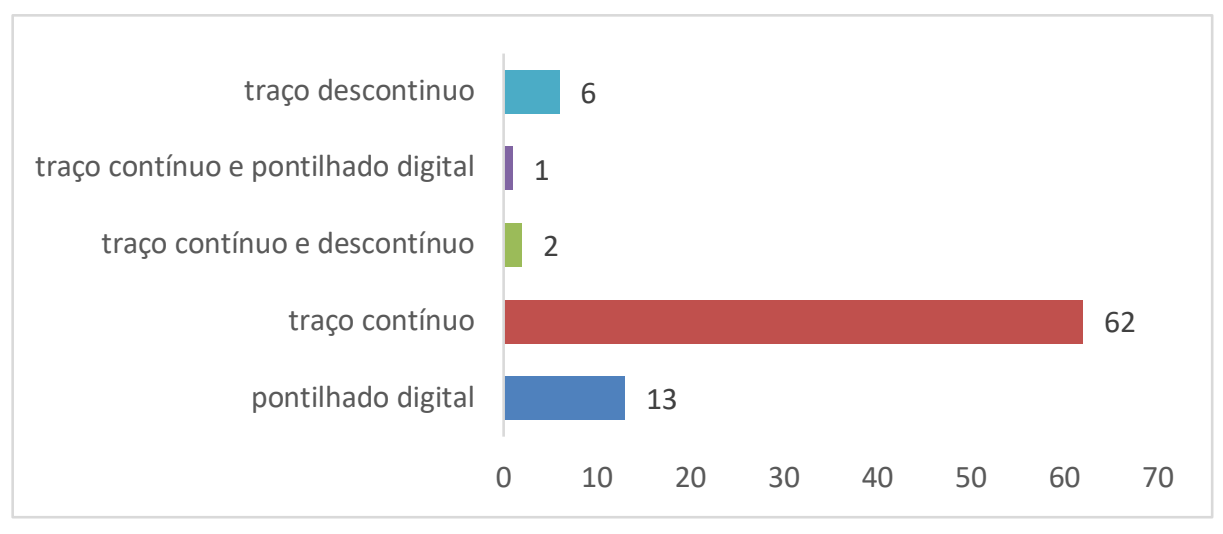

Quadro 5: Parâmetros de técnica

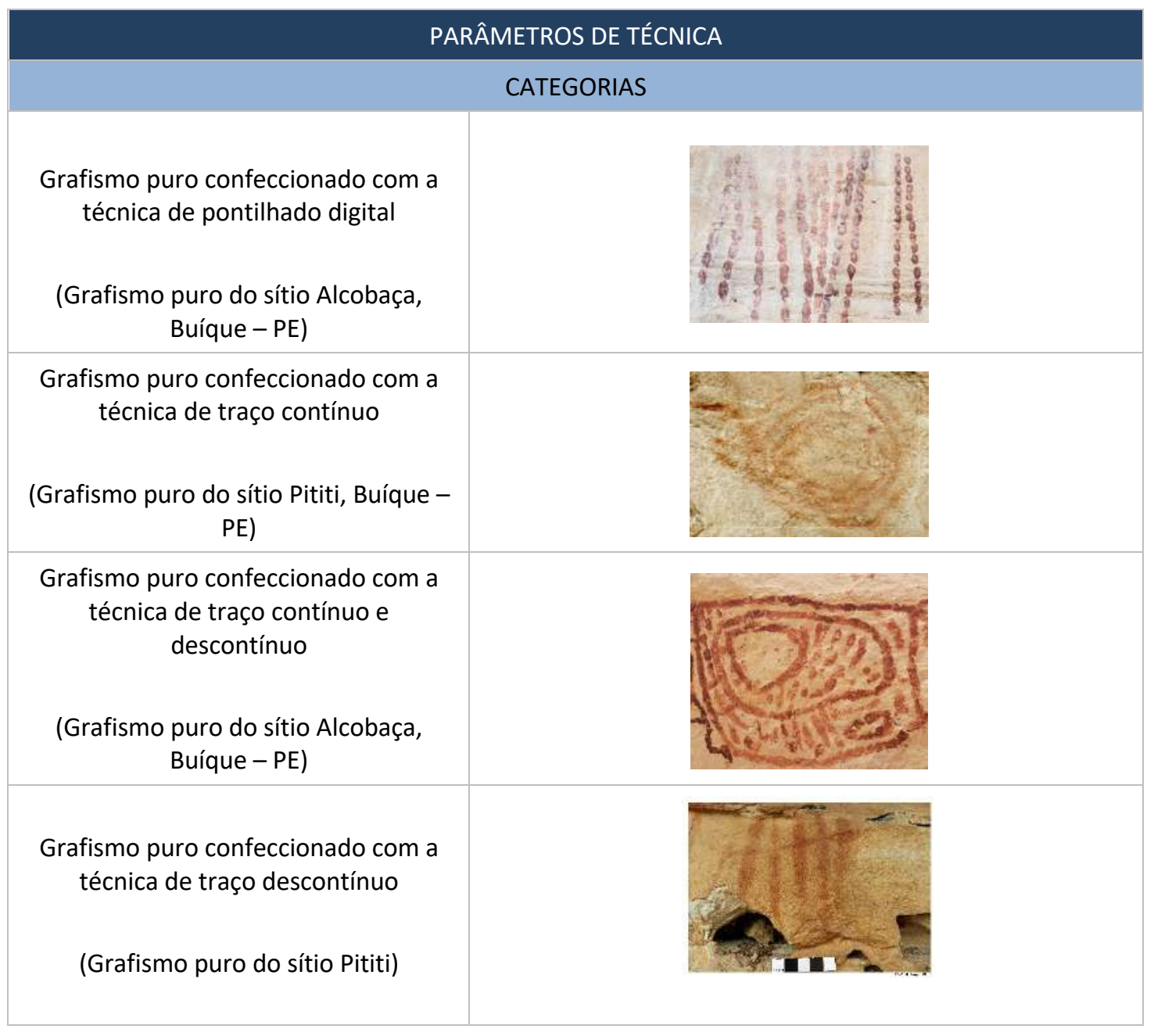




\section{Discussão e Resultados}

O presente trabalho procurou caracterizar os grafismos puros do Parque Nacional do Catimbau, uma área de grande importância dentro da pesquisa arqueológica, por meio de uma metodologia que procurou responder a problemática suscitada, bem como contribuir com o conhecimento arqueológico sobre este tipo de manifestação de registro rupestre na referida área de análise.

Os grafismos puros não reconhecíveis são aqueles em que seu reconhecimento não é imediato pelo pesquisador, exigindo uma identificação anterior; exigindo pesquisas posteriores para que a sua abordagem seja feita de forma a se tentar conceber as "chaves do seu código, e obter as provas de que estas chaves estão corretas" (GUIDON, 1982). Ao conceber o grafismo puro como mais um componente da cultura material de um determinado grupo social (ou de grupos sociais), as diferenças estilísticas podem ser utilizadas para os identificar, caracterizar e abordar de maneira direcionada. Através do registro rupestre, podem ser definidos territórios, quer do ponto de vista espacial como social e cultural, assim como estabelecer relações entre grupos que poderão partilhar o mesmo espaço ou espaços adjacentes.

O trabalho exposto teve por finalidade analisar os grafismos puros do Parque Nacional do Catimbau, privilegiando o sistema morfológico, estes grafismos representam um conjunto particular no universo gráfico dos grupos pré-históricos.

Observou-se na amostra alguns grafismos formados por linhas sinuosas que poderiam ser confeccionados como espécie de carimbos, esses grafismos possuem uma delimitação de seu espaço gráfico bastante preciso. Desta forma, em relação as variáveis, observou-se alguns conjuntos que se sobressaíram na amostra.

1. Morfologia - Os grafismos sem forma definida, que foram aqui classificados como tipo "carimbos", são minoritários, porém apesar de não ter forma definida, esses grafismos, expressam muito mais uma simetria técnica em relação ao traço do que os demais grafismos; Formas circulares - essas formas dominam os tipos estudados, em geral preenchidas por círculos concêntricos, as linhas que formam esses círculos não se tocam; nas Formas quadrangulares e retangulares, dominam as linhas paralelas.

2. Técnica - Pontilhados digitais - estes estão mais associados a forma quadrangulares e retangulares, não se observa formas circulares ou semicirculares com essa técnica. 
Traços contínuos - são dominantes dentro dos sítios analisados. Esse traço não possui uma homogeneidade de espessura ao longo do traçado, o que não lhe confere precisão e simetria em sua forma.

Traços descontínuos - são recessivos dentro dos sítios analisados. Assim como os traços contínuos, esses também não possuem homogeneidade de espessura tampouco precisão e simetria.

Assim, a análise dos grafismos puros do Parque Nacional do Catimbau possibilitou observar que embora não existam cópias similares em tamanho e espessura do traço, há uma tendência à repetição de algumas formas gerais, tais como: círculos concêntricos, formas carimbadas, quadrangulares e retangulares formado por linhas paralelas. $O$ que apresenta uma inclinação para inferir que a forma do grafismo permite elaborações fluídas de traço e tamanho, e que o elemento mais regulador desses grafismos seria sua expressão gráfica geral, ou seja a ideia abstrata da morfologia.

\section{Referências}

AGUIAR, A. 1986. A tradição Agreste: estudo sobre arte rupestre em Pernambuco. Revista Clio - Série Arqueológica. n. 3, Recife, UFPE, p. 7-78.

AlBuRQuerque, M., LUCENA, V. 1987. Caçadores Coletores no Agreste Pernambucano: Ocupação e Ambiente Holocênico. Clio, Série Arqueologia, Recife: UFPE, V. 1, n. 4, Anais do I Simpósio de PréHistória do Nordeste do Brasileiro. p. 73-74, 1991, Número extraordinário.

ALEMANY, F. P. 1986. El Calendário Solar da "Pedra de Ingá: una hipotesis de trabajo. Instituto de Arqueologia Brasileira.

AMARAL, M. P. V. do. 2015. As pinturas rupestres da tradição agreste em Pernambuco e na Paraíba Brasil. Tese (Doutorado) Universidade Federal de Pernambuco, Programa de Pós-Gradução em Arqueologia.

BELTRÃO, M. 1994. As Pinturas Rupestres da Chapada Diamantina e o Mundo Mágico-Religioso do Homem Pré-Histórico Brasileiro. [S.I.]: Organização Oderbrecht.

BONELL, C. 2006. La Geometria y la vida: Antologia de Alazuelo. Madrid: Ed. Murcia.

CALDERON, V. 1983 [1967]. Nota Prévia Sobre Três Fases da Arte Rupestre no Estado da Bahia. Estudos de Arqueologia e Etnografia. Salvador: UFBA, p. 5-23.

CISNEIROS, D. 2008. Similaridades e diferenças nas pinturas rupestres pré-históricas de contorno aberto no Parque Nacional Serra da Capivara - PI. Tese (Doutorado em Arqueologia). Universidade Federal de Pernambuco.

CISNEIROS, D. 2010. Similaridades e Diferenças nas Pinturas Rupestres Pré-Históricas de Contorno Aberto no Parque Nacional Serra da Capivara - Pi. Clio. Série Arqueológica (UFPE), v. 24, p. 12-25, 2010. 
COMERLATO, F. 2005. As Representações Rupestres do Estado de Santa Catarina. Revista OHUN, Bahia, UFBA, p. 150-164.

CORREA, A. C de B., CAVALCANTI, L.C de S., LIRA, D. R. de. 2015. Stone and Sands Ruins in the Drylands of Brazil: The Rustic Landscapes of Catimbau National Park. World Geomorphological Landscapes. v.22.

CORREIA, M. F. dos S. B. Gravuras Rupestres no Vale do Moxotó, Pernambuco-Brasil: um estudo da técnica de execução da cenografia do conjunto gráfico. Dissertação (Mestrado em Arqueologia), Universidade Federal de Pernambuco, 2016.

GUIDON, N. 1975. Les Peintures Rupestres de Várzea Grande, Piauí, Brésil. Cahiers d’Archéologie d`Ameririque du Sul. Paris, Écoloe de Hautes Étude em Sciences Sociales, n. 3.

GUIDON, N. 1981. Tradições e estilos da Arte Rupestre no Sudeste do Piauí. Pré-história Brasileira Aspectos da Arte Parietal. Catálogo de Exposição. São Paulo, USP, p.19-20.

GUIDON, N. 1982. Da aplicabilidade das classificações preliminares na arte rupestre. Revista Clio. n.5.

GUIDON, N. 1989. Tradições Rupestres da Área Arqueológica de São Raimundo Nonato, Piauí, Brasil. Revista Clio - Série Arqueológica, Recife, n. 5, p. 5-10.

GUTIÉRREZ, R. M. 2012. Teorías interpretativas del arte rupestre. Revista Tiempo y Sociedad. n.9.

IBAMA. 2002. Decreto, s/n, de 13 de dezembro de 2002. Dispõe sobre a criação do Parque Nacional do Catimbau, nos Municípios de Ibimirim, Tupanatinga e Buíque, no Estado de Pernambuco, e dá outras providências. Brasília.

MARTIN, G. 1982. O Estilo Seridó na arte rupestre do Rio Grande do Norte. Arquivos do Museu de História Natural. Belo Horizonte: MHNJB/UFMG, v. 6-7, p. 379-383.

MARTIN, G. 2013. Pré-história do Nordeste do Brasil. Recife: EDUFPE.

MONZON, S. 1982. Métodos de Análise de grafismos de ação. Arquivos do Museu de História Natural, v. 6-7. Belo Horizonte, UFMG, p. 353-364.

OLIVEIRA, A. L. do N. 2001. O Sítio arqueológico Alcobaça: Buíque, Pernambuco - Estudo das estruturas arqueológicas. Tese de Doutoramento, Programa de Pós-graduação em História da Universidade Federal de Pernambuco-UFPE, Recife, 186 p. il.

PESSIS, A-M. 1984. Métodos de Interpretação da Arte rupestre: Análises preliminares por níveis. Revista Clio Arqueológica. n.6.

PESSIS, A-M. 1984. Registros Rupestres: perfil gráfico e grupo social. Revista de Arqueologia. v.8. n.1.

PESSIS, A-M. 1987. Art rupestre préhistorique: Premiers registres de la mise en scene. Tese (doutorado de Estado) - Université de Paris X - Nanterre.

PESSIS, A-M. 1992. Identidades e Classificações dos registros gráficos pré-históricos do nordeste do Brasil. Clio Arqueológica, v.1, n.8.

PESSIS, A-M. 1993. Registros rupestres, perfil gráfico e grupo social. Revista Clio - Série Arqueológica, Recife, n. 9, p. 7-14,

PESSIS, A-M. 2003. Imagens da Pré-história. Parque Nacional da Serra da Capivara, FUMDHAM/PETROBRAS. 
PESSIS, A-M. e GUIDON, N. 2000. Registro Rupestre e Caracterização das Etnias Pré-Históricas. In: VIDAL, Lux (org.). Grafismo Indígena: Estudos Em Antropologia Estética. 2a ed. São Paulo: Studio Nobel; Fapesp; Edusp. Pp. 19-33.

PESSIS, A.; CISNEIROS, D; MUTZENBERG, D. 2018. Identidades Gráficas nos Registros Rupestres do Parque Nacional Serra da Capivara, Piauí, Brasil. FUMDHAMentos, v. XV, p. 26-48, 2018.

PESSIS, A.;CISNEIROS, D. ; MUTZENBERG, D. MARTIN, G. ; LAVALLE, H. 2017. Caracterização dos Sítios Pré-Históricos com Grafismos Rupestres no Estado de Pernambuco, Brasil. Revista Clio Arqueológica, v. 32, p. 165.

PIETTE, E. 1907. L' Art pendant l' Age du Renne. Paris: Ed. Masson.

PROENÇA A. L. 2010. Reconhecimento Arqueológico na Região do Catimbau: Prospecção, Geoprocessamento e Estratigrafias no Contexto Arqueológico. Revista de Geografia. Recife: UFPE DCG/NAPA, v. especial VIII SINAGEO, n. 2, p. 288-301.

PROUS, A. 1992. Arqueologia Brasileira. Brasília - DF: Ed. UnB.

SANCHIDRÍAN, J.L. 2018. Manual de Arte Prehistórico. Ed. Ariel Prehistoria: Barcelona.

SAUVET, G. 1990. Les signes dans l'art mobilier. In J. Clottes (dir.) Les objets au Paléolithique supérieur. Tome 2 : les voies de la recherche. Colloque de Foix-Le Mas d'Azil (1987). Dir. Patrimoine, p. 83-99.

SCHIMITZ, P. I.; BARBOSA, A.; RIBEIRO, M. B.; VERADI, I. 1984. Arte Rupestre no Centro do Brasil: pinturas e gravuras da pré-história de Goiás e oeste da Bahia. São Leopoldo: Instituto Anchietano de Pesquisa / Unisinos.

SOARES, F. F. 2003. Expressões Gráficas na Ilha do Campeche - SC. Porto Alegre: Dissertaçao de mestrado do Programa de Pós-Graduação em História da PUCRS. 